\title{
Upper Wenlock miospores and cryptospores derived from a Silurian volcanic island in the Prague Basin (Barrandian area, Bohemia)
}

\author{
PAVEL DUFKA \\ Czech Geological Survey, Klárov 131/3, 11821 Praha 1, Czech Republic.
}

\begin{abstract}
Highly-diversified assemblages of dispersed trilete miospores and cryptospores belonging to the Artemopyra brevicosta-Hispanaediscus verrucatus Assemblage Zone were recovered from upper Wenlock (Silurian) tuffitic shales and limestones in the Prague Basin (Bohemia). The fact that the numerous sporomorphs have only been found in the region of the Svaty Jan Volcanic Centre supports previous sedimentological evidence that this volcanic elevation was emerged during the uppermost Wenlock. Twenty-nine sporomorph forms were determined. One new genus, Rugosisporites gen. nov., and three new species, Rugosisporites kozlicus sp. nov., Synorisporites maculosus sp. nov. and Artemopyra rugaticosta sp. nov. are described. The comparison with other coeval assemblages is discussed. J. Micropalaeontol. 14(1): 67-79, April 1995.
\end{abstract}

\section{INTRODUCTION}

The objective of this paper is a study of upper Wenlock sporomorphs from the Prague Basin. No Silurian sporomorphs have been published from the basin prior to this study. The first trilete miospores described from the basin come from upper Pragian (Devonian) Dvorce-Prokop Limestone (McGregor, 1979; Vavrdová, 1989).

\section{Facies development and land plant traces in the Silurian of the Prague Basin}

During the Silurian the Prague Basin was a part of north Gondwanan shelf seas bordering the Rheic ocean, fairly distant from large emergent lands. Anoxic bottom conditions generally occurred across the shelves. During the Llandovery and lower Wenlock such conditions, represented by black shale facies, existed in nearly the whole Prague Basin (see in Kř̃̌z, 1991). In the deeper parts of the basin they persisted until the middle Devonian.

From the mid-Wenlock to the early Ludlow the sedimentation in the Prague Basin was influenced by volcanic activity related to deep synsedimentary faults and their zones of intersections (K Ǩřz, 1991). The accumulation and redeposition of volcanic material caused a considerable shallowing of the central segment of the Prague Basin resulting in the deposition of bioclastic limestones in the region of the Svatý Jan Volcanic Centre (Fiala, 1982; Horný, 1955; Kř̃̌z, 1991). These limestones contain within the $C$. murchisoni Graptolite Biozone the oldest trilete miospores (Ambitisporites avitus Hoffmeister and Ambitisporites dilutus Hoffmeister) so far discovered in the Silurian of the Prague Basin (Dufka, 1990). Volcanic activity together with late Wenlock (late Homerian) regression lead to continuous shallowing and consequent emergence of the top of the volcanic elevation (Kǔřž, 1991). The new island may have favoured the rapid development of early land plants.
Numerous dispersed sporomorphs produced by these plants were deposited in tidal flat sediments.

Lack of sporomorphs in a number of samples of lower Ludlow (Gorstian) sediments from the vicinity of the Svaty Jan Volcanic Centre suggests the extinction of the upper Wenlock land flora due to submergence of the island or further volcanic activity.

Sporomorphs in the upper Ludlow and lower Prídolí strata are absent or rare and poorly preserved. However, based on sedimentological evidence, the top of the island was probably still above the sea level during this period (Křžž, 1991). Additionally, occurrences of Cooksonia-like sporophytes from lower Prídolí rocks (Obrhel, 1962) suggest that the recurrence of an island flora could be possible and the absence of sporomorphs may be caused by lack of outcrops within the upper Silurian near-shore deposits.

\section{COLLECTED DATA AND PALYNOLOGICAL TECHNIQUES}

This paper on upper Wenlock sporomorphs is the outcome of the palynological investigations carried out within the new palaeontological and biostratigraphic study of the Wenlock/Ludlow boundary in the Prague Basin (Kř̃̃̃ 1992).

The majority of accessible upper Wenlock (Homerian, Motol Formation) and lower Ludlow (lower Gorstian, Kopanina Formation) sections in the Prague Basin have been investigated for organic microfossils. Sporomorphs, however, have been recovered only from late Wenlock strata of the central part of the basin, in the area of Svatý Jan Volcanic Centre (sensu Kříž, 1991, p. 182). The Motol Formation is developed here in facies containing bioclastic and tuffitic limestones and tuffites ('Kozel' facies) associated with basalt and volcaniclastic rocks (Horný, 1955; Kř̃̃z, 1991). In contrast to lateral deeper parts of the Prague Basin, where the sedimentation of graptolite shales 


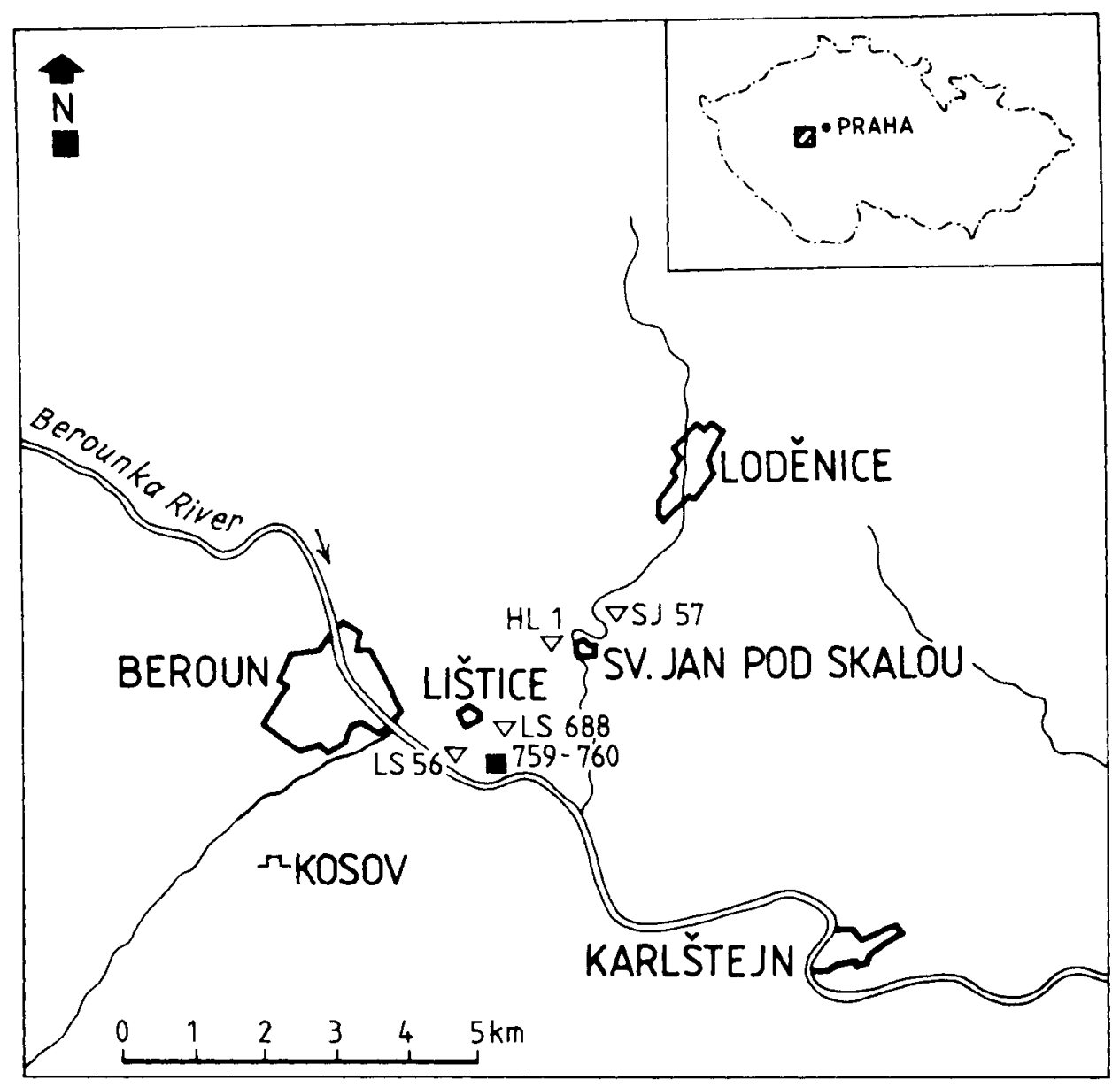

Fig. 1. Location of the outcrops with sporomorph occurrences.

continued, the richness of benthic fauna and dearth of graptolites characterise this volcano-carbonate facies.

Twenty-three samples from five outcrops have yielded some sporomorphs (Figs 1 and 2).

The most significant specimens of sporomorphs yet found come from tuffites, tuffitic shales and limestones forming the eastern part of the large rock outcrop above the Berounka river, near the village of Lištice. General study of these rocks was done by Horný (1955) and more detailed biostratigraphy was discussed by Kříž (1992). Kříž defined here two sections (759 and 760; for detail see Kř́̌ž, 1992) separated by layers of tuffitic shales and volcaniclastics, more than forty metres thick, covered with slope debris. Graptolites of the $C$. lundgreni Biozone ( $M$. priodon flemingii) were found in the lower section no. 759 (Křiž, 1992). These graptolite data together with new intrabasinal correlation of the overlying volcaniclastics (J. Krř̃̌z, pers. comm.) suggest that the tuffites and bioclastic limestones of the section no. 760 may range from the $M$. dubius parvus Biozone to the $M$. vulgaris Biozone, Wenlock, Silurian.

Beside the first outcrop there were also a few samples containing sporomorphs taken from test pits situated near the Svatý Jan Volcanic Centre (Fig. 1). These samples are not dated by graptolites. According to previous studies
(Horný, 1955; Kř́ž́, pers. comm.) the age of host rocks corresponds to Homerian. Following four samples were collected from dug holes: sample HL-1 (brachiopod limestone) Svatý Jan, 'Hlinik' locality (Horný, 1955); sample SJ-57 (crinoid limestone) Svatý Jan, 'ruda' horizon; sample LS-56 (tuffite) Lištice; sample LS-688 (bioclastic limestone) Lištice, 'Hradiště' locality.

All samples were processed using standard palynological techniques (HCl-HF-HCl-heavy liquid separation). No oxidation was applied. Organic residue was sieved through $53 \mu \mathrm{m}$ and $10 \mu \mathrm{m}$ nylon sieves. Light microphotographs were made with a Zeiss-Fluoval. Electron Microscope (SEM) photos were taken with a TESLA BS 340 SEM.

\section{CHARACTERISTICS OF THE PALYNOSPECTRA}

Based on the relative abundance of sporomorphs and acritarchs, recorded in each sample, two upper Wenlock palynofacies with spores could be distinguished.

\section{A. Section 759 (all samples), sample SJ-57, sample HL-1, sample LS-688}

Trilete miospores and cryptospores are distinctly less abundant compared with marine microphytoplankton. Sporomorphs are mostly ill-preserved, except for the sample 


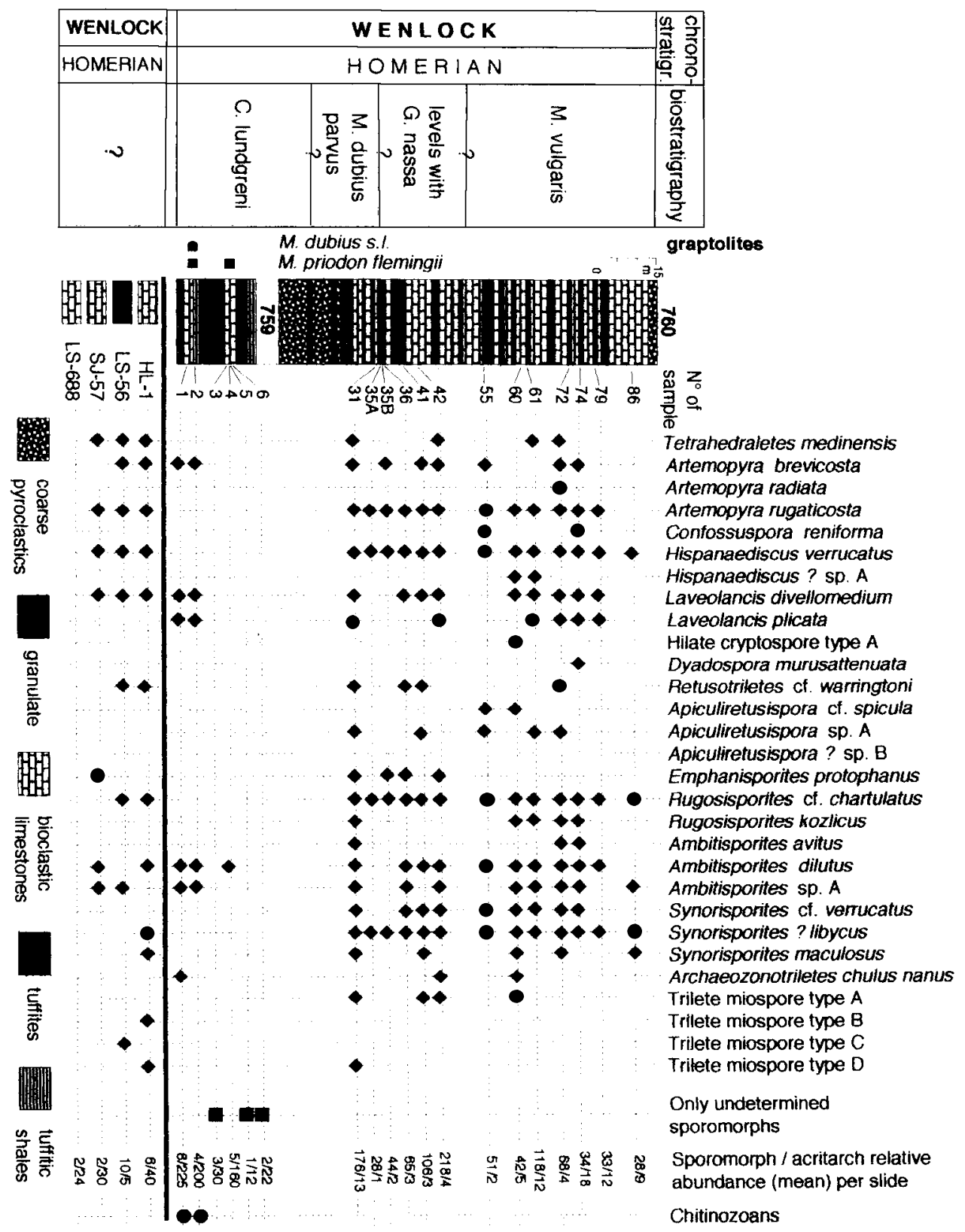

Fig. 2. Distribution of trilete miospores and cryptospores in the upper Wenlock strata of the Prague Basin.

HL-1, where the specimens are well-preserved. In spite of the low content of sporomorphs a high specific diversity including sculptured forms was recorded in samples $\mathrm{HL}-1$ and SJ-57 (Fig. 2). Acritachs and prasinophycean-like sphaeromorphs dominate the palynospectra. Their absolute abundance, however, is fairly low $(<50$ specimens/g in sample HL-1). The distribution and number of acritarchs are similar to those of prasinophytes in all samples. Acritarchs are mostly light-yellow, excellently preserved and of high variability.

Chitinozoans were recovered only from two samples of section 759 (Fig. 2). Two long-ranging species, Ancyrochitina group ancyrea Eisenack and Conochitina tuba Eisenack, were recognized.

\section{B. Section 760 (all samples)}

Trilete miospores and cryptospores clearly predominate over the marine microphytoplankton. Their mode of preservation ranges from well-preserved specimens that exhibit all fine details of the wall ornamentation to specimens destroyed by microbial attack or pyrite crystal grows. Sporomorph colour ranges between light and dark 


\begin{tabular}{|c|c|c|c|c|c|c|c|c|}
\hline \multirow{2}{*}{ 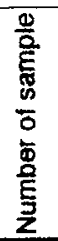 } & \multicolumn{4}{|c|}{ TRILETE MIOSPORES } & \multirow[t]{2}{*}{ TETRADS } & \multicolumn{3}{|c|}{ HILATE CRYPTOSPORES } \\
\hline & Laevigate & Murornate & Apiculate & Verrucate & & Laevigate & Murornate & Verrucate \\
\hline 72 & 17 & 21 & 2 & 19 & 2 & 9 & 6 & 24 \\
\hline 61 & 11 & 10 & 1 & 33 & $<1$ & 6 & 6 & 33 \\
\hline 42 & 15 & 8.5 & - & 26 & $<1$ & 6 & 8 & 36.5 \\
\hline 41 & 7 & 9 & 2 & 23 & - & 11 & 7 & 41 \\
\hline 36 & 10 & 13.5 & $<1$ & 33 & - & 5.5 & 8 & 29.5 \\
\hline 31 & 5 & 15.5 & $<1$ & 29 & 2 & 6 & 10 & 32 \\
\hline
\end{tabular}

Fig. 3. Percentages of various morphological groups of sporomorphs in selected samples from the section no. 760.

brown, depending on sample lithology and exine thickness. The abundance and species diversity of sporomorphs vary slightly in individual samples, nevertheless they have an approximately uniform character throughout the section. All samples are characterized by dominance of distally verrucate miospores and cryptospores, by the common occurrence of murornate and laevigate miospores and cryptospores and by the scarcity of 'permanently' fused cryptospore dyads and tetrads (Fig. 3).

Acritarchs are rare, but well-preserved. Together with prasinophycean-like algae they represent maximally $10 \%$ of counted palynomorphs, except for the uppermost three samples in the section where they constitute nearly $25 \%$ of recorded palynomorphs.

No chitinozoans have been found in the section.

\section{Sample LS-56}

Sporomorphs are scarce, but diversified. Acritachs are also rare, represented by ill-preserved, small spherical forms with short simple processes (?Micrhystridium, ?Tylotopalla). No chitinozoans were found. A substantially increased content of amorphous kerogen indicates anoxic bottom conditions.

In all studied samples the occurrence of further macerals was noted, but they are not yet classified. No mazuelloids have been found in sporomorph-containing samples. Scolecodonts are common. Nematothallus-type pseudocellular cuticles are commonly found compared with nematoclasts ('tubes') which are rare. In general, the number of sporomorphs does not increase together with the number of Nematothallus-type organoclasts. Similarly, the abundance of macroscopically fragments of organic matter formed by closely packed filaments (cf. Prototaxites Dawson) in upper Wenlock tuffitic shales and limestones can not be correlated with occurrences of sporomorphs.

\section{SYSTEMATIC DESCRIPTIONS}

Anteturma Cryptosporites Richardson et al., 1984

Genus Artemopyra Burgess \& Richardson, 1991

Artemopyra brevicosta Burgess \& Richardson, 1991

Remarks. Artemopyra Burgess \& Richardson, 1991 is regarded as a synonym of Dicryptosporites Strother, 1991. The publication dates give evidence that the genus Artemopyra has precedence over the genus Dicryptosporites. Dicryptosporites radiatus Strother, 1991 is transferred to the genus Artemopyra and Dicryptosporites minus Strother, 1991 is considered as a junior synonym of Artemopyra brevicosta Burgess \& Richardson, 1991.

Artemopyra radiata (Strother, 1991) comb. nov. (Pl. 1, fig. 6)

1991 Dicryptosporites radiatus Strother: 226, pl. 1, fig. 6. Diagnosis. See Strother, 1991, p.226

Description. Hilate cryptospores seen only as separate grains. Amb circular to subcircular. Proximal hilum surrounded by thickened equatorial ring. Hilum ornament with radially arranged ribs running out from the equatorial ring, extending about $1 / 4$ of spore diameter and then passing into the 'inner ring' of concentrical muri or wrinkles. Hilum usually smooth in polar area. Distal exine laevigate.

Dimensions. 12 specimens measured: equatorial diameter (mean value of each specimen) $24(25) 28 \mu \mathrm{m}$.

Remarks. Artemopyra brevicosta Burgess \& Richardson has shorter radial muri sculpturing the equatorial ring rather than the surface of the hilum. Artemopyra rugaticosta sp. nov. has mainly convoluted and anastomosing muri usually distributed throughout the hilum without a discernable 'inner ring'. 
Artemopyra rugaticosta sp. nov.

(Pl. 1, figs 2, 5, 11)

? 1973 Emphanisporites cf. micrornatus Richardson \& Lister, Richardson \& Ioannides: 275, pl. 3, fig. 4.

? 1978 Emphanisporites protoannulatus Rodriguez: 416, pl. 1 , figs $22,23$.

1991 Artemopyra sp. A, Burgess \& Richardson: 613, pl. 1, figs 10,11 .

Diagnosis. An Artemopyra with more or less radially orientated proximal muri (wrinkles), usually convolute and anastomosing or composing rugulate ornamentation.

Holotype. Pl. 1, fig. 11; sample 760/74; slide 760/74-J. Czech Geological Survey.

Paratype. Pl. 1, fig. 5; sample 760/41; slide 760/41-C. Czech Geological Survey.

Type locality and type horizon. Section 760 (Křĩ̌, 1992), Lištice near Beroun, Prague Basin. Barrandian area, Czech Republic. Motol Formation, upper Homerian, Wenlock, Silurian.

Description. Hilate cryptospores, probably derived from loosely attached dyads, but all specimens seen are single grains. Amb circular to subcircular. Equatorial rim mostly distinct, $1-2 \mu \mathrm{m}$ wide, surrounding the proximal hilum. Hilum sculptured with low muri or wrinkles distinctive by more or less radial orientation (at least close to the equator), convolute, anastomosing or rugulate patterns and gradual tapering to the proximal pole. Exceptionally, muri are nearly straight extending from the equator to the proximal pole (paratype). Distal exine is $c .1 \mu \mathrm{m}$ thick, laevigate.

Dimensions. 30 specimens measured: equatorial diameter 20(24)34 $\mu \mathrm{m}$.

Remarks. Artemopyra radiata (Strother) comb. nov. has shorter distinctly radial muri and smooth polar portions of the proximal exine.

Genus Hispanaediscus Cramer, 1966, emend. Burgess \& Richardson, 1991

Hispanaediscus verrucatus Cramer 1966

Hispanaediscus? sp. A

(Pl. 1, figs 12, 13)

Description. Hilate cryptospores found as separate grains. Amb subcircular. Proximal hilum sculptured with radial muri, straight or anastomosing, always converging at the proximal pole. Distal exine covered by low, sparce verrucae, circular or oval in outline.

Dimensions. 3 specimens measured: equatorial diameter $28,30,35 \mu \mathrm{m}$.

Remarks. Hispanaediscus wenlockensis Burgess \& Richardson 1991 has closely packed distal verrucae and shorter proximal radial muri.

\section{Hilate cryptospore type A}

$$
\text { (Pl. 2, figs 1, 2) }
$$

Description. Proximally hilate cryptospores. Amb circular. Equatorial crassitude forms a narrow ring, about $1 \mu \mathrm{m}$ wide. Proximal hilum rugulate. Distal exine sculptured with regularly distributed shallow foveolae which are surrounded by low annular thickenings.

Dimensions. 2 specimens recorded: equatorial diameter $20 \mu \mathrm{m}$.

Anteturma Sporites H. Potonié, 1893

Turma Triletes Reintsch, 1891

Subturma Azonotriletes Luber, 1935

Infraturma Apiculati Bennie \& Kidston, emend. Potonié, 1956

Genus Apiculiretusispora Streel, 1964

Apiculiretusispora brandtii Streel, 1964 Apiculiretuspora sp. A

(Pl. 2, fig. 16)

Description. Amb subcircular to convex triangular. Laesurae straight, simple or accompanied with lips parallel with laesurae extending from $3 / 4$ of to entire spore radius. Contact areas smooth, often distinct, delimited by well-defined curvaturae perfectae, smooth. Outside of contact areas exine ornamented with minute, dense grana or low spines.

Dimensions. 5 specimens measured: equatorial diameter 24(26) $29 \mu \mathrm{m}$.

Remarks. Apiculiretusispora sp. A Richardson \& Lister (1969) is much larger in diameter. Apiculiretusispora sp. A Richardson \& Ioannides (1973) has a distinctly smaller contact area.

\section{Apiculiretusispora? sp. B}

(Pl. 2, fig. 3)

1973 Apiculiretusispora sp. B Richardson \& Ioannides; 274 , pl. 2, fig. 6 .

Description. Amb subcircular to broadly triangular. Laesurae mostly inconspicuous. Ornamentation consisting of small cones or spines, about $0.5 \mu \mathrm{m}$ high.

Dimensions. 4 specimens measured: equatorial diameter 13-18 $\mu \mathrm{m}$.

Infraturma Murornati Potonié \& Kremp, 1954

Genus Rugosisporites gen. nov.

Rugosisporites chartulatus (McGregor) comb. nov.

Derivation of name. Latin rugosus, wrinkled

Diagnosis. Radial trilete miospores; amb subtriangular to subcircular. Proximal surface sculptured with short and low muri, rugulae or grana radially and/or randomly orientated. Equatorial crassitude inconspicuous, distal exine laevigate or with scattered minute grana.

Comparison. Emphanisporites McGregor has proximal muri which are predominantly radial, continuously tapering to the proximal pole.

Rugosisporites cf. chartulatus (McGregor 1979) comb. nov. (Pl. 2, figs 9-14)

1973 Emphanisporites? sp. D Richardson \& Ioannides; 276, pl. 3, fig. 9 .

1978 Retusotriletes chartulatus McGregor in McGregor \& Narbonne; 1301, pl. 1, figs. 10-12.

1991 Trilete miospore type 1 Burgess \& Richardson; 618, text fig. $3 \mathrm{~A}-\mathrm{C}$. 
Description. Amb subtriangular to subcircular. Equatorial crassitude narrow $(<2 \mu \mathrm{m})$. Laesurae distinct, more or less sinuous, simple or with inconspicuos lips, extending from $4 / 5$ to entire spore radius. Curvaturae perfectae either coincident with the equator or slightly to distinctly invaginate. Proximal surface (contact area) rugulate, composed of numerous tiny muri or wrinkles, usually convolute and anastomosing which are somewhat randomly disposed, but in general radially aligned, predominantly near the equator. Distal exine laevigate or hearing scattered minute grana.

Dimensions. 55 specimens measured: equatorial diamater $20(25) 31 \mu \mathrm{m}$.

Remarks. The specimens described by McGregor in McGregor \& Narbonne (1978, p.1301) as well as the Trilete miospore type 1 of Burgess \& Richardson (1991) are substantially larger than the forms of Rugosisporites cf. chartulatus from the Prague Basin. Nevertheless their morphological features are fairly similar.

\section{Rugosisporites kozlicus sp. nov.} (P1. 2, figs 15, 17)

Diagnosis. A Rugosisporites with straight Laesurae and minute proximal ornamentation, consisting of randomly orientated small ruguae and grana.

Holotype. Pl. 2, fig. 17, sample 760/61, slide 760/61-A. Czech Geological Survey.

Type locality and type horizon. Section 760 (Křî̃, 1992), Lištice near Beroun, Prague Basin. Barrandian area, Czech Republic. Motol Formation, upper Homerian, Wenlock, Silurian.

Description. Amb circular to subcircular laesurae simple, straight, extending near or to the spore margin. Equatorial crassitude indistinct. Curvaturae perfectae coincident with the equator. Proximal surface sculptured with numerous, short, randomly orientated ruguae and grana. Distal exine laevigate.

Dimensions. 8 specimens measured: equatorial diameter 25(28)31 $\mu \mathrm{m}$.

Remarks. Rugosisporites cf. chartulatus (McGregor) comb. no. has more distinct, radially orientated proximal ruguae and often invaginated curvaturae.

\section{Subturma Zonotriletes Waltz, 1935 in Luber \& Waltz (1938)}

Infraturma Crassiti Bharadwaj \& Venkatachala, 1961

Genus Ambitisporites Hoffmeister, 1959

Ambitisporites avitus Hoffmeister, 1959

\section{Ambitisporites sp. A}

(Pl. 3, fig. 11)

Description. Small Ambitisporites $(<20 \mu \mathrm{m}$ in diameter). Amb subtriangular to subsphaerical. Laesurae distinct, simple, extenting near or to the spore margin. Curvaturae coincident with the equator. Exine laevigate.

Dimensions. 15 specimens measured: equatorial diameter 15(18) $20 \mu \mathrm{m}$.

Remarks. Ambitisporites sp. A is closely similar to Ambitisporites dilutus Hoffmeister 1959, but substantially smaller than supposed for $A$. dilutus. For example, Burgess \& Richardson (1991, p. 615) did not report a specimen of $A$. dilutus smaller than $22 \mu \mathrm{m}$ among 100 specimens of $A$. dilutus from type Wenlock area.

Genus Synorisporites Richardson \& Lister, 1969

Synorisporites downtonensis Richardson \& Lister, 1969

Synorisporites cf. verrucatus Richardson \& Lister, 1969

(Pl. 3, figs 5, 6)

1973 Synorisporites cf. verrucatus Richardson \& Lister; Richardson \& Ioannides: 278, pl. 6, figs. 11-16

Dimensions. 20 specimens measured: equatorial diameter $18(21) 26 \mu \mathrm{m}$.

Remarks. Specimens referred to Synorisporites cf. verrucatus have a little more prominent and closely packed verrucae in comparison with forms assigned to Synorisporites libycus Richardson \& Ioannides (see below).

Synorisporites ? libycus Richardson \& Ioannides, 1973 (Pl. 3, figs 4, 7, 8, 12, 13)

Dimensions. 50 specimens measured: equatorial diameter $18(24) 30 \mu \mathrm{m}$.

Remarks. The specimens referred here to Synorisporites libycus? are more or less conformable with the descriptions of Richardson \& Ioannides (1973, p.280) and Burgess \& Richardson (1991; Synorisporites cf. S. ? libycus, p. 617). They dominate among verrucate miospores in section 760 and may be discriminated from Synorisporites cf. verrucatus by lower and more separated verrucae confined within the equatorial thickening. However, the morphological characteristics of both the species from the Prague Basin appear to intergrade (more than those of the Libyan forms).

Synorisporites maculosus sp. nov. (Pl. 3, figs 1-3)

Derivation of name. Latin maculosus, speckled.

\section{Explanation of Plate 1}

Homerian of the Prague Basin (see Fig. 4). Enlargement: all figs $\times 1500$ Figs 1, 4. Artemopyra cf. brevicosta Burgess \& Richardson, 1991 . Fig. 1. 760/42-E. Fig. 4. 760/31-J. Figs 2, 5, 11. Artemopyra rugaticosta sp. nov. Fig 2. 760/74-H. Fig. 5. Paratype, 760/41-C. Fig. 11. Holotype, 760/74-J. Fig. 3. Artemopyra cf. rugaticosta sp. nov., 760/74-H. Fig. 6. Artemopyra radiata (Strother, 1991) comb. nov., 760/72-D. Fig. 7. Confossuspora reniforma Strother, 1991, 760/74C. Figs 8-10. Hispanaediscus verrucatus Cramer, 1966, emend. Burgess \& Richardson, 1991. Fig. 8. 760/60-G. Figs 9, 10.760/74-B, proximal and distal focus respectively. Figs 12, 13. Hispanaediscus? sp. A, 760/35-B, proximal and distal focus respectively. 


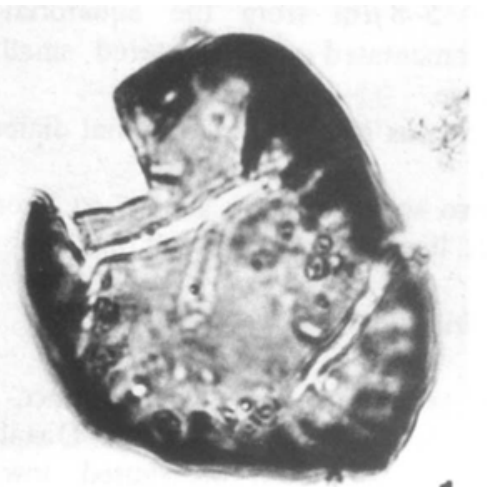

$-1$

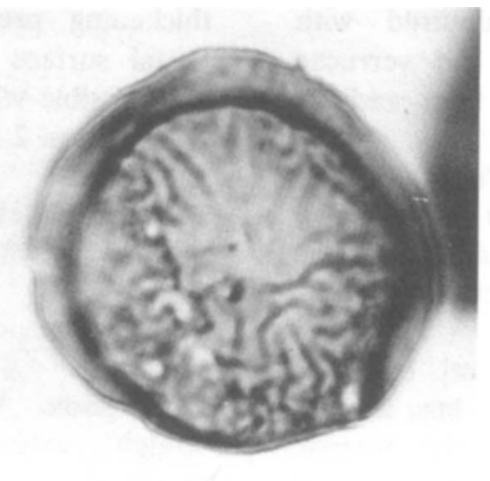

2
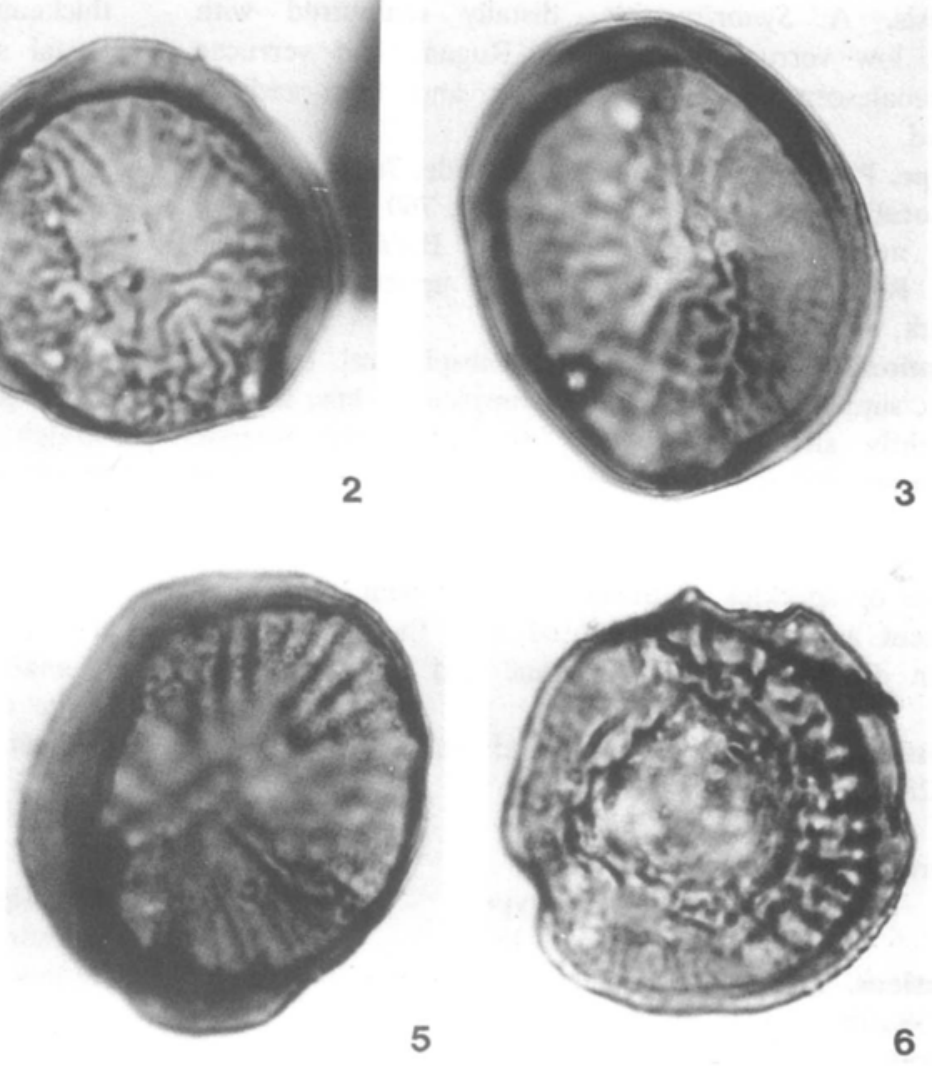

3

4
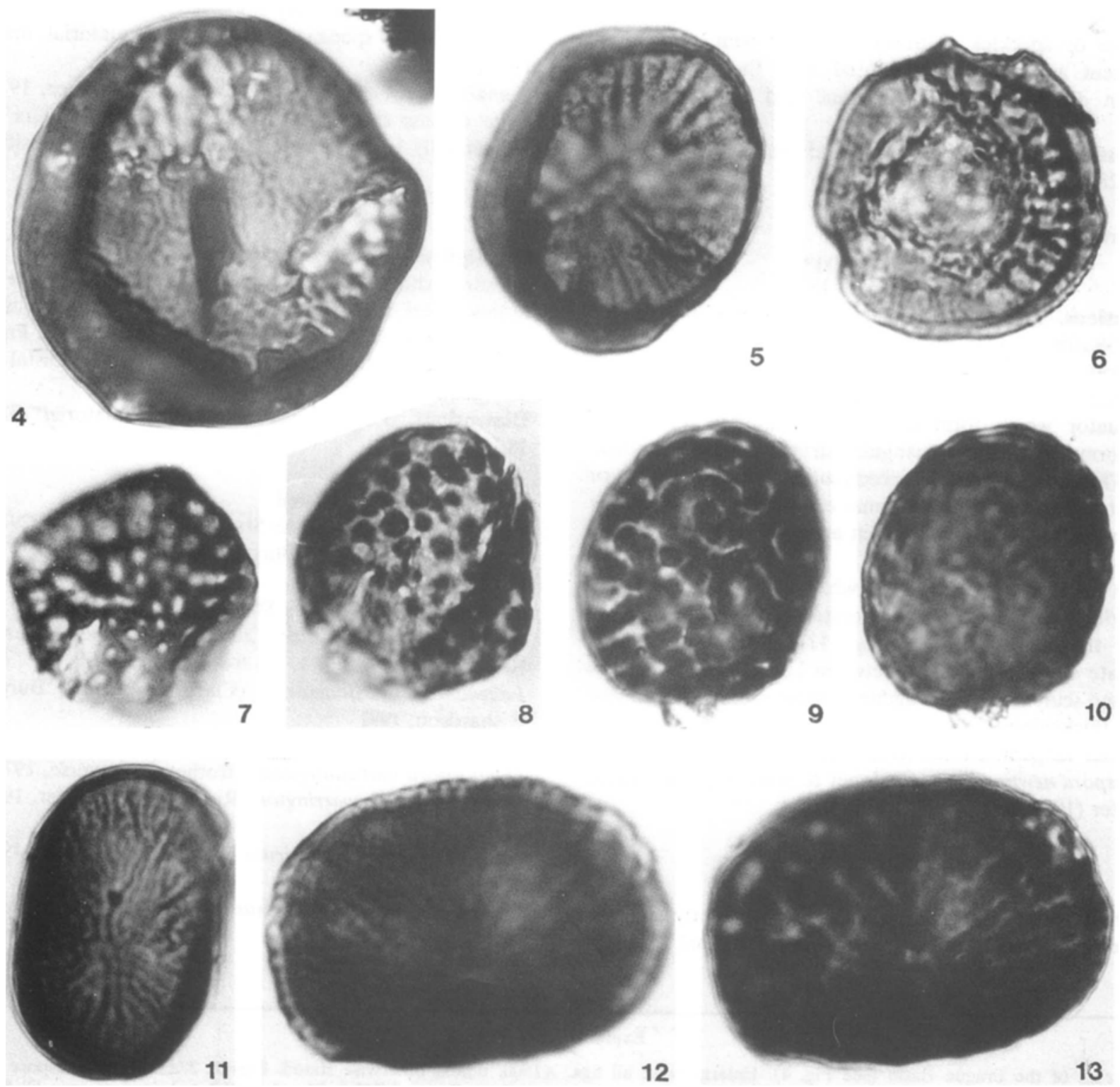

Plate 1. 
Diagnosis. A Synorisporites, distally sculptured with ruguae, low verrucae and grana. Ruguae and verrucae often coalescent near the equator and then radially disposed.

Holotype. P1. 3, fig. 1, sample 760/41, slide, 760/41-C.

Type locality and type horizon. Section 760 (Křžz, 1992), Lištice near Beroun, Prague Basin. Barrandian area, Czech Republic. Motol Formation, upper Homerian, Wenlock, Silurian.

Description. Amb subtriangular to subspherical. Laesurae distinct, simple or with narrow inconspicuous lips, straight or slightly sinuous, extending to the spore margin. Curvaturae coincident with the equator. Proximal exine mostly laevigate or covered with small grana and wrinkles. Distal surface ornamented with ruguae, grana and low verrucae or speckles of thickened exine which are often coalescent and radially orientated near the equator and rare on distal pole. Both proximal and distal walls are thin.

Dimensions. 13 specimens measured: equatorial diameter 23(25) $28 \mu \mathrm{m}$.

\section{Indeterminate trilete miospores}

Trilete mispore type $\mathrm{A}$

(PI. 3, figs 16-18)

Dimensions. 12 specimens measured: equatorial diameter 31(33) $38 \mu \mathrm{m}$.

Description and remarks. A group of trilete miospores characterized by narrow thickenings, more or less parallel to equator which form conspicuous equilateral triangle. Two forms bearing this triangular structure were recorded.

1. Thickennings distal, accompanied with granulate or rugulate ornamentation. Proximal exine smooth; curvaturae straight, extending to the margin and curvaturae coinciding to the equator (Pl. 3, fig. 16).

2. A triangle composing belts which seem to be proximal, bordering the trilete mark. Laesurae are sometimes sunk under thickennings ( $\mathrm{Pl}$. 3, fig. 17). Proximal exine is laevigate or microgranulate between Laesurae and thickenings, and sculptured with ruguae or short radial muri outside of the thickenings.

Similar tangential folds were described and illustrated on Streelispora newportensis (Chaloner \& Streel) by Richardson \& Lister (1969, p. 230, pl. 41, fig. 3).

\section{Trilete miospore type B} (Pl. 3, fig. 9)

Description. Amb subspherical. Laesurae slightly sinuous, extending nearly to spore margin. Proximal annular thickening present $5-8 \mu \mathrm{m}$ from the equatorial edge. Distal surface ornamentated with spattered small grana and possible verrucae.

Dimensions. 2 specimens measured: equatorial diameter 26 and $27 \mu \mathrm{m}$.

Remarks. These two specimens are similar to Spore type D of Richardson \& Ioannides (1973, pl. 9, fig. 2).

Trilete miospore type C

(PI. 3, figs 14, 15)

Description. Amb subcircular. Laesurae distinct, mostly straight, extending to the spore margin. Distal exine provided with low, chaotically distributed low muri, convoluted and anastomosing to form irregular reticulum. Proximal surface probably smooth.

Dimensions. 4 specimens measured: equatorial diameter $19-21 \mu \mathrm{m}$.

Remarks. Archaeozonotriletes vetustus Rodriguez, 1977 has more or less similar distal sculpture, but it differs by its substantially larger size and a thick equatorial crassitude.

Trilete miospore type $\mathrm{D}$ (Pl. 2, figs 4-6)

Description. Amb subtriangular with rounded apices. Laesurae short, extending maximally for $1 / 2$ of the spore radius. Polar area delimiting laesurae convex and triangular in outline, smooth or sparsely microgranulate. Proximal radial ribs confined onto equatorial area. Distal exine laevigate.

Dimensions. 3 specimens measured: equatorial diameter $18,20,24 \mu \mathrm{m}$.

\section{Other species determined}

Tetrahedraletes medinensis Strother \& Traverse, 1979

Artemopyra brevicosta Burgess \& Richardson, 1991 (Pl. 1, figs 1,4$)$

Confossuspora reniforma Strother, 1991 (PI. 1, fig. 7)

Hispanaediscus verrucatus Cramer, 1966, emend. Burgess \& Richardson, 1991 (Pl. 1, figs 8-10)

Laveolancis divellomedium (Chibrikova, 1959) Burgess \& Richardson, 1991

L. plicata Burgess \& Richardson, 1991

Dyadospora murusattenuata Strother \& Traverse, 1979

Retusotriletes cf. warringtoni Richardson \& Lister, 1969 (Pl. 2, fig. 18)

Apiculiretusispora cf. spicula Richardson \& Lister, 1969 (PI. 2, fig. 19)

Emphanisporites protophanus Richardson \& Ioannides, 1973 (Pl. 2, figs 7, 8)

\section{Explanation of Plate 2}

Homerian of the Prague Basin (see Fig. 4). Enlargement: all figs. $\times 1500$, unless otherwise stated. Figs 1, 2. Hilate cryptospore type A, 760/60-B, proximal and distal focus respectively. Fig. 3. Apiculiretusispora? sp. B, HL-1/V2-2. Figs 4-6. Trilete miospore type D. Figs 4, 5. HL-1/V-5, proximal and distal focus respectively. Fig. 6. 760/31-C. Figs 7, 8. Emphanisporites protophanus Richardson \& Ioannides, 1973, 760/31-C, proximal and distal focus respectively. Figs 9-14. Rugosisporites cf. chartulatus (McGregor) gen. et comb. nov. Fig. 9. 760/31-E. Fig. 10. 760/72-E. Fig. 11. 760/72-O. Fig. 12. 760/79-A, ×1750. Fig. 13. 760/31-J. Fig. 14. 760/72-B. Figs 15, 17. Rugosisporites kozlicus gen. et sp. nov. Fig. 15. 760/61-H. Fig. 17. holotype, 760/61-A. Fig. 16. Apiculiretusispora sp. A, 760/72-B. Fig. 18. Retusotriletes cf. warringtoni Richardson \& Lister, 1969, HL-1/U-1. Fig. 19. Apiculiretusispora cf. spicula Richardson \& Lister, 1969, 760/55-C. 
Upper Wenlock miospores and cryptospores
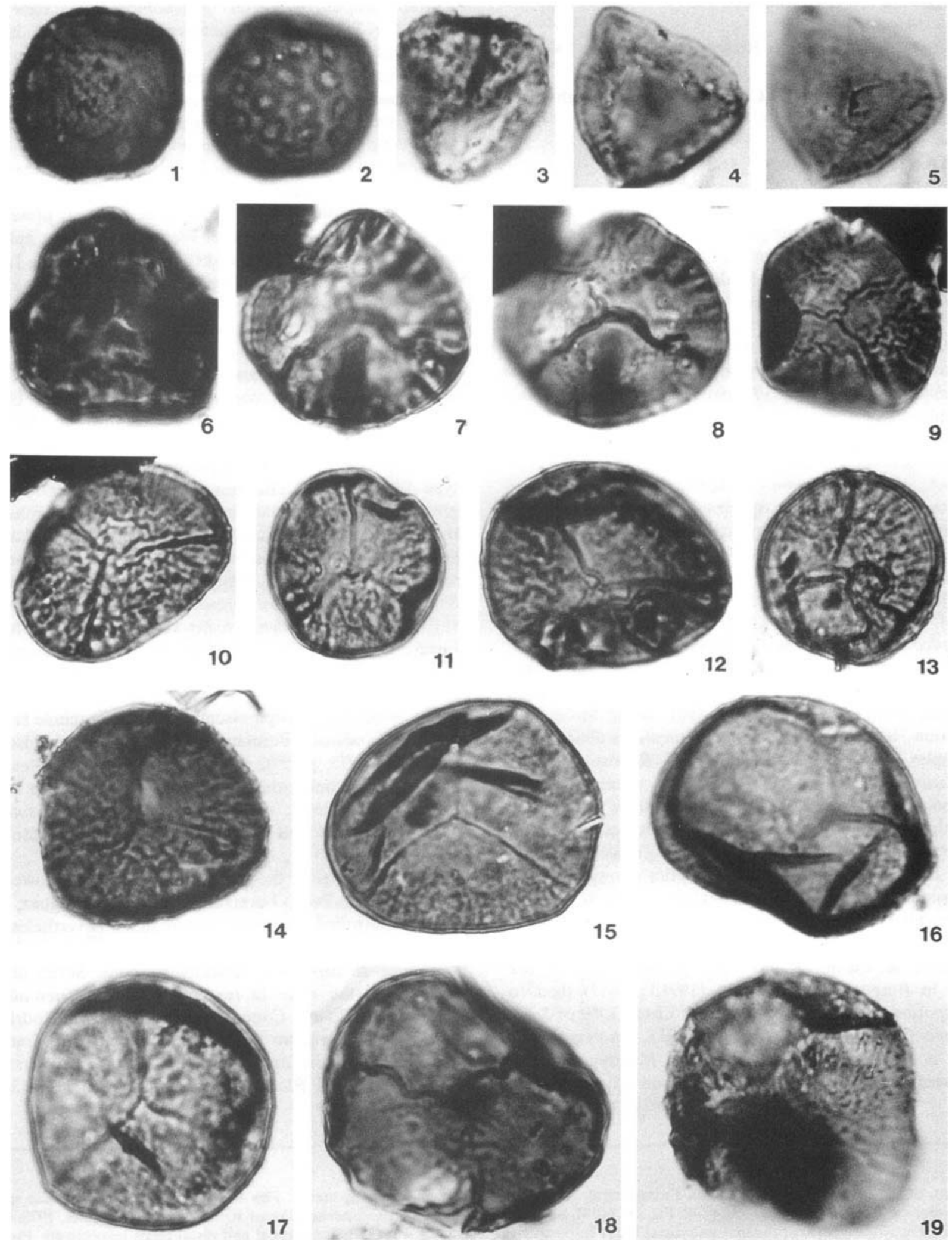

Plate 2. 
Ambitisporites avitus Hoffmeister, 1959

A. dilutus Hoffmeister 1959

Synorisporites cf. verrucatus Richardson \& Lister, 1969 (Pl.

3, figs 5, 6)

Archaeozonotriletes chulus (Cramer) var. nanus Richardson \& Lister, 1969 (Pl. 3, fig. 10)

\section{BIOSTRATIGRAPHY AND DISCUSSION}

In the biozonal scheme proposed by Richardson \& McGregor (1986) for Silurian and Devonian sporomorphs, the Wenlock strata encompass two assemblage zones of sporomorphs: Archaeozonotriletes chulus var. chulus-A. chulus var. nanus (late Llandovery to late Wenlock, Telychian to late Homerian) and ?Emphanisporites cf. protophanus-cf. Synorisporites verrucatus (late Wenlock to early Ludlow, late Homerian to early Gorstian). The latter was recently emended by Burgess \& Richardson (1991) to Artemopyra brevicosta-Hispanaediscus verrucatus Assemblage Zone.

In the Prague Basin, scarce sporomorphs (150 specimens) from the section 759 may be assigned to $A$. chulus var. chulus-A. chulus var. nanus Assemblage Zone based on presence of characteristic species and total absence of sculptured forms. Other assemblages from the section 760 as well as from samples HL-1 and SJ-57 containing well-diversified ornamented sporomorphs belong to A.brevicosta-H.verrucatus Assemblage Zone.

\section{A. brevicosta-H. verrucatus Assemblage Zone}

Both index species, Hispanaediscus verrucatus Cramer, 1966, emend. Burgess \& Richardson and Artemopyra brevicosta Burgess \& Richardson, 1991, range throughout the section 760 . However, while $H$. verrucatus is abundant in all samples, $A$. brevicosta is rather rare. Rugosisporites cf. chartulatus (McGregor) comb. nov. is a characteristic, commonly found, species ranging throughout the section 760. Fairly similar forms have been recently described from the Homerian of the type Wenlock area (Trilete miospore type 1; Burgess \& Richardson, 1991). Thus this species may be considered as an additional significant taxon for this sporomorph Zone. Most of the distally verrucate miospores from section 760 are more similar to ? Synorisporites libycus Richardson \& Ioannides, 1973 and Synorisporites cf. S.? libycus in Burgess \& Richardson (1991, p. 617) than to Synorisporites verrucatus Richardson \& Lister, 1969 or S. cf. verrucatus (Richardson \& Ioannides, 1973). Synorisporites? libycus is mentioned by Richardson \& McGregor (1986) only from the overlying Ludlow biozone (Synorisporites
libycus-?Lophozonotriletes poecilomorphus). New data from the Prague Basin, however, indicate that its first occurrence is already in the $A$. brevicosta-H. verrucatus Assemblage Zone. The forms of $S$. verrucatus (cf. verrucatus) having distinct equatorial thickenings and closely packed prominent verrucae have not been recovered from upper Wenlock samples in the Prague Basin. Emphanisporites protophanus Richardson \& Ioannides, 1973 has been found in four samples of the section no. 760. This occurrence documents for the first time the early presence of E. protophanus in the late Wenlock. Unique apiculate miospores which are supposed to appear only in the Ludlow S. libycus-? L. poecilomorphus Assemblage Zone were recorded from several samples. However, their classification is vague due either to their scarcity or bad preservation.

\section{Comparison with other assemblages}

Scarce records of the upper Wenlock and lower Ludlow sporomorphs were summarized by Richardson \& McGregor (1986, p. 8, 9) and Burgess \& Richardson (1991, table 3).

The sporomorph assemblages recently described from the type Wenlock area (Burgess \& Richardson, 1991) are of great importance for the correlation with sporomorphs from the Prague Basin, because they are independently dated by graptolites, including the interval of the first appearance of sculptured sporomorphs. Only three species described from Shropshire, Dyadospora murusdensa Strother \& Traverse, 1979, Archaeozonotriletes chulus var. chulus Richardson \& Lister, 1969 and Hispanaediscus wenlockensis Burgess \& Richardson, 1991 are absent in the coeval sediments in the Prague Basin.

The lower sporomorph assemblage from borehole samples of the Tanezzuft Formation in Libya (Richardson \& Ioannides, 1973 ; p.259), roughly dated by graptolites, also displays close similarities with assemblages from the Prague Basin. Except for A. chulus var. chulus and Retusotriletes minor Kedo, 1963 all Libyan species have been found in section 760 .

The assemblage of the spore Zone 1a from the lowermost part of the San Pedro Formation in Spain (Rodriguez, 1978) is not controlled by index macrofauna, nevertheless the recorded palynospectrum indicates presence of the $A$. brevicosta-H. verrucatus Assemblage Zone. Seven of nine forms from the zone 1a, excepting Retusotriletes abundo Rodriguez, 1978 and Convolutispora sanpetrense Rodriguez, 1978, are known from the Prague Basin. North American assemblages of the upper Wenlock (Strother \& Traverse, 1979; Burgess \& Richardson, 1991, p. 621) and Ludlow

\section{Explanation of Plate 3}

Homerian of the Prague Basin (see fig. 4). Enlargement: all figs. $\times 1500$, unless otherwise stated. Figs 1-3. Synorisporites maculosus sp. nov. Fig. 1. holotype, 760/41-C. Fig. 2. 760/41-A. Fig. 3. 760/31-B. Figs 4, 7, 8, 12, 13. Synorisporites libycus Richardson \& Ioannides, 1973 . Fig. 4. 760/61-H. Figs. 7, 8. 760/31, proximal and distal focus respectively. Figs 12, 13. 760/35B-C, proximal and distal focus respectively. Figs 5, 6. Svnorisporites cf. verrucatus Richardson \& Lister, 1969,760/72H, proximal and distal focus respectively. Fig. 9. Trilete miospore type B, HL-1/B-II-4, ×2000. Fig. 10. Archaeozonotriletes chulus (Cramer) var. nanus Richardson \& Lister, 1969, 760/72-L. Fig. 11. Ambitisporites sp. A, 760/31-A. Figs 14, 15. Trilete miospore type C, LS-56/2, proximal and distal focus respectively. Figs 16-18. Trilete miospore type A. Fig. 16. 760/42-C. Fig. 17. 760/31, slide GSP-S-1, scaning electron microphotograph showing proximal surface with laesurac and tangential thickenings. Fig. $18.760 / 31-\mathrm{F}$ 

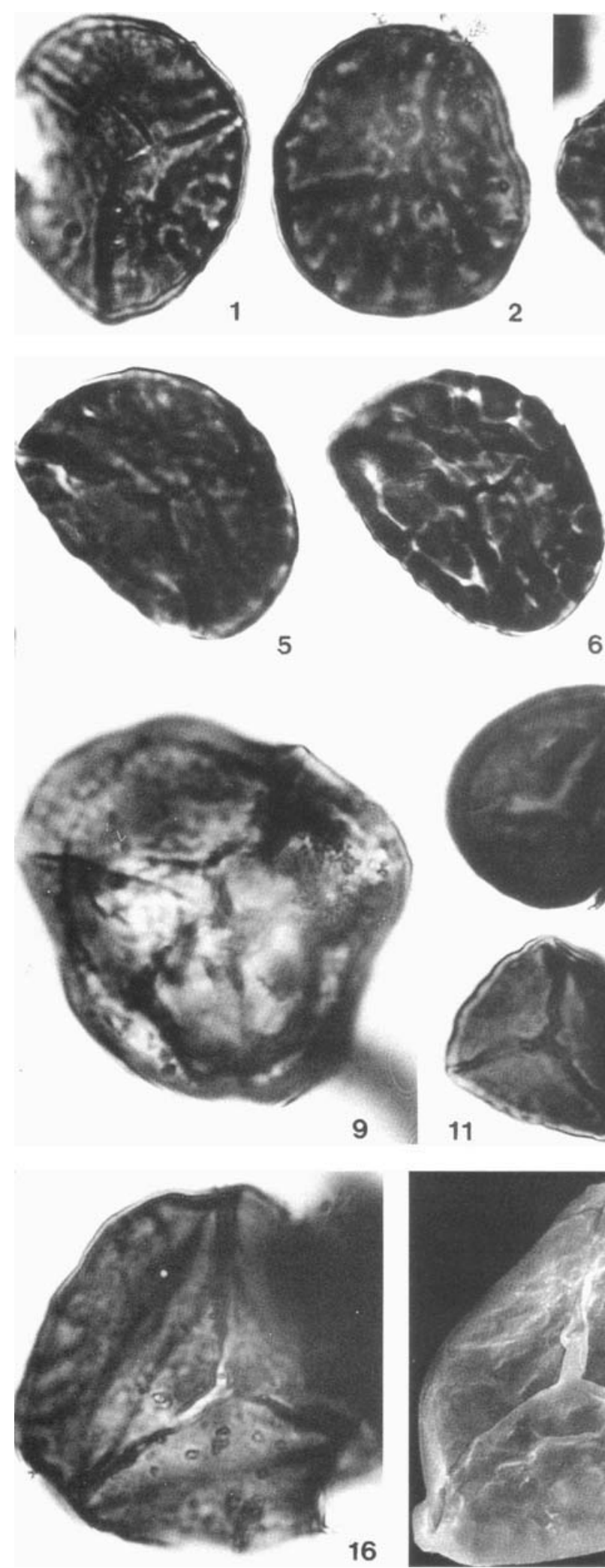

16

11
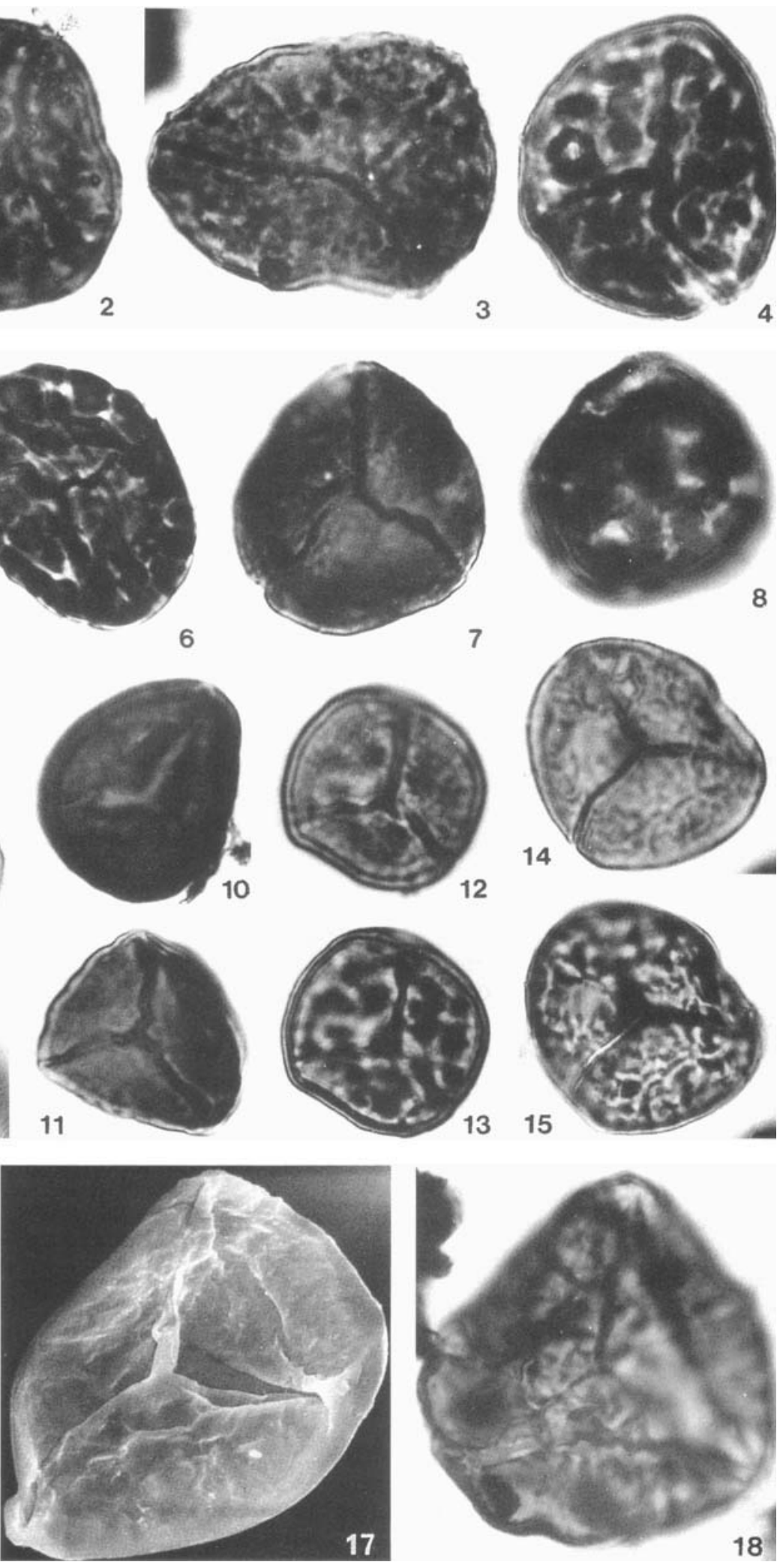

Plate 3. 


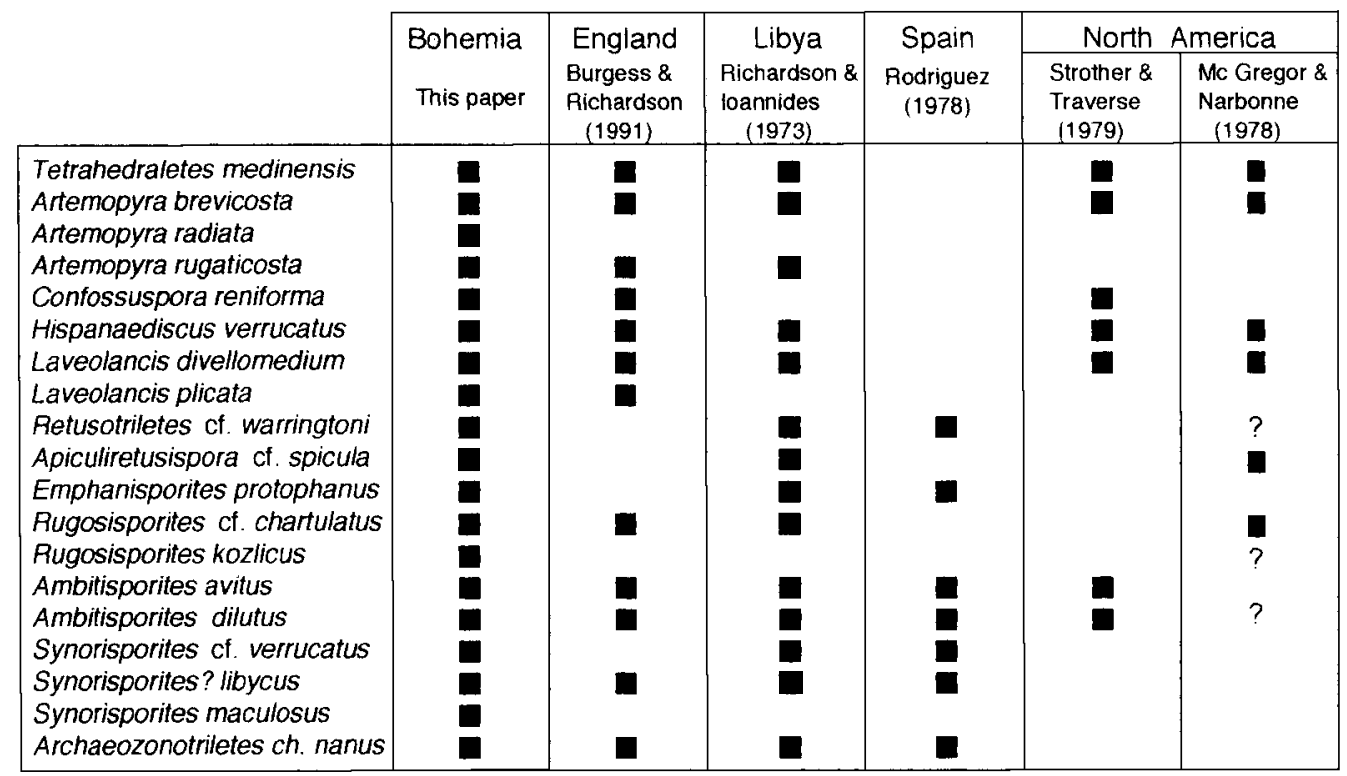

Fig. 4. Selected Homerian sporomorphs from the Prague Basin and in upper Wenlock and lower Ludlow assemblages around the world.

(McGregor \& Narbonne, 1978) which comprise index species of $A$. brevicosta-H. verrucatus Assemblage Zone show considerable resemblance in the species spectra and morphological variability of sporomorphs with the Homerian assemblages of the Prague Basin.

In spite of the rare occurrence of trilete miospores and cryptospores in the Prague Basin, there are significant similarities between these assemblages and coeval assemblages from England, Libya, Spain and North America (Fig. 4). A conformity of the species spectra may indicate some communication between those distant areas by means of spore dispersal. Sporomorphs might be transported over a great distance most probably by strong surface currents, similar to the transport of larvae of benthic fauna. However, because of their small size (mean diameter of sporomorphs below $25 \mu \mathrm{m}$ ), wind transport of spores cannot be excluded (for discussion see Fanning et al., 1988). In general, the mentioned resemblance of upper Wenlock/lower Ludlow sporomorph assemblages supports the previous ideas about the uniform evolution of the land flora during the upper Silurian (e.g. Edwards, 1990), at least in the North Atlantic Region (sensu Boucot, 1990, fig. 1).

\section{ACKNOWLEDGEMENTS}

I would like to thank Paul K. Strother, Florentin Paris and Jiři Křž for constructive criticism of my manuscript and to John B. Richardson for helpful discussions on spore systematics.

\section{Manuscript received January 1993 Manuscript accepted March 1994}

\section{REFERENCES}

Boucot, A. J. 1990. Silurian biogeography. In McKerrow, W. S. \& Scotese, C. R. (Eds), Paleozoic Paleogeography and Biogeography. Geological Society, London, Memoir, 12: 191-196.

Burgess, N. D. \& Richardson, J. B. 1991. Silurian cryptospores and miospores from the type Wenlock area, Shropshire, England. Palaeontology, 34: 601-628.

Edwards, D. 1990. Constraints on Silurian and Early Devonian phytogeographic analysis based on megafossils. In McKerrow, W. S. \& Scotese, C. R. (Eds), Paleozoic Paleogeography and Biogeography. Geological Society, London, Memoir, 12: $233-242$.

Fanning, U., Richardson, J. B. \& Edwards, D. 1988. Cryptic evolution in an early land plant. Evolutionary Trends in Plants, 2: $13-24$.

Fiala, F. 1982. Basaltoid diabase from Hostim with indications of hematite mineralisation. Casopis pro mineralogii a geologii, 27: $173-185$.

Horný, R. 1955. The Budñany Beds in the western part of the Silurian of the Barrandian. Sbornik Ustredního ústavu geologického, oddíl geologický, 21: 315-409.

Kř̃ž, J. 1991. The Silurian of the Prague Basin (Bohemia)-tectonic, eustatic and volcanic controls on facies and faunal development. Special Papers in Palaeontology, 44: 179-203.

Kř́žz, J. 1992. Silurian field excursions: Prague Basin (Barrandian) in Bohemia. National Museum of Wales, Geological Series 13, Cardiff.

McGregor, D. C. 1979. Devonian spores from the Barrandian region of Czechoslovakia and their significance for interfacies correlation. Geological Survey of Canada, Paper 79-1B: 189-197.

McGregor, D. C. \& Narbonne, G. M. 1978. Upper Silurian trilete spores and other microfossils from the Read Bay Formation, Cornwallis Island, Canadian Arctic. Canadian Journal of Earth Sciences, 15: 1292-1303.

Obrhel, J. 1962. Die Flora der Prídolí-Schichten (Budnany-Stufe) des mittelb/mischen Silurs. Geologie, 11: 83-97.

Richardson, J. B. \& loannides, N. S. 1973. Silurian palynomorphs from the Tanezzuft and Acacus Formations, Tripolitania, North Africa. Micropaleontology, 19: 257-307.

Richardson, J. B. \& Lister, T. R. 1969. Upper Silurian and Lower 
Upper Wenlock miospores and cryptospores

Devonian spore assemblages from the Welsh Borderland and South Wales. Palaeontology, 12: 201-252.

Richardson, J. B. \& McGregor D. C. 1986. Silurian and Devonian spore zones of the Old Red Sandstone continent and adjacent regions. Geologigal Survey of Canada, Bulletin, 364: 1-79.

Rodriguez, R. M. 1978. Mioesporas de la Formacion San Pedro/Furada (Silurico Superior - Devonico Inferior), Cordillera Cantabrica, NO de Espana. Palinologia, Numero Extraordinario, 1: $407-433$.
Strother, P. K. 1991. A classification scheme for the cryptospores. Palynology, 15: 219-236. Dallas.

Strother, P. K. \& Traverse, A. 1979. Plant microfossils from Llandoverian and Wenlockian rocks of Pennsylvania. Palynology, 3: 1-21.

Vavrdová, M. 1989. Early Devonian palynomorphs from the Dvorce-Prokop Limestone (Barrandian region, Czechoslovakia). Vèstník Ústredniho ústavu geologického, 64: 207-224. 